\title{
CHROMOSOME BANDING PATTERNS OF THE GUDGEON, GOBIO GOBIO (ACTINOPTERYGII, CYPRINIDAE)
}

\author{
Lech KIRTIKLIS *, Alicja BOROŃ, Katarzyna PORYCKA \\ Division of Zoology, Faculty of Biology, University of Warmia and Mazury in Olsztyn, Poland
}

Kirtiklis L., Boroń A., Porycka K. 2005 Chromosome banding patterns of the gudgeon, Gobio gobio (Actinopterygii, Cyprinidae). Acta Ichthyol. Piscat. 35 (2): 119-123.

Background. The gudgeon is one of the most divergent fish species in Europe. Morphological variability related to sex, size, ecological characters, and geographical distribution are well documented in the literature. Apart from the only few data on the karyotype, chromosome banding patterns of this species have not been studied. Cytogenetic features are very useful tools in taxonomic descriptions of cyprinid species. The aim of this study was to describe and characterise the banding patterns of the gudgeon karyotype.

Material and methods. Cytogenetic examinations of 15 specimens of gudgeon from the upper part of the Odra River, Poland, were carried out. Different chromosome banding techniques: Giemsa staining, C-banding, silver nitrate, chromomycin $\mathrm{A}_{3}$ and DAPI staining were used.

Results. The karyotype of gudgeon consisted of $2 \mathrm{n}=50$ chromosomes, and NF $=98$ chromosome arms. AgNORs were located on one submeta-subtelocentric chromosome pair and the size polymorphism of NORs was detected. The chromosome sites with G-C rich DNA on one submeta-subtelocentric chromosome pair and heterochromatin block in the centromeric regions were found. Low accumulation of A-T pair rich regions were indicated by DAPI staining.

Conclusion. The presently described new chromosomal features of Gobio gobio substantially enhance our knowledge on the taxonomy of this species at cytogenetic level. Jointly with data on morphological- and genetic variability they could be used to determine the phylogeny of the genus Gobio and related species.

Key words: chromosome banding patterns, gudgeon, Gobio gobio, fish, karyotype, NOR polymorphism

\section{INTRODUCTION}

The Gobioninae, along with other seven subfamilies, belongs to the family Cyprinidae (cf. Howes 1991). Hosoya (1986) considered them to be monophyletic, based on sensory canal patterns, morphology of supraoccipial and frontal, and modification of the anterior vertebrae. Three species; G. gobio, G. kessleri, and G. albipinnatus, occurring in Poland, have been traditionally assigned to the genus Gobio. According to Bănărescu (1992) G. gobio from Europe, Siberia, and Central Asia represents Gobio sensu stricto. Naseka (1966) divided the genus Gobio sensu Bănărescu into two genera Gobio and Romanogobio, and the latter genus containing two other species: R. kessleri and R. albipinnatus. Among Gobioninae only Gobio has a wide distribution range, extending throughout most of Europe, the Black Sea watershed in northern Anatolia, several landlocked lakes in Central Anatolia, some rivers in Central Asia, and most of Siberia in the watershed of the Arctic Ocean as far east as the Lena and Kolyma rivers (Bănărescu 1999). Many geographical populations of this fish, classified as subspecies or "nations" have been described within its geo- graphical range. According to Bănărescu (1999) five European subspecies are now recognised.

The majority of the morphological characters of the Gobio species and specifically the gudgeon, G. gobio, such as sexual dimorphism, age, growth, feeding habits, longevity, and some aspects of reproduction biology have been already described (see a review of Bănărescu 1999). G. gobio, considered one of the most divergent fish species in Europe, with high level of interpopulational variability, has not been studied in relation to its banding chromosomal patterns. However, some cytogenetic features as C-banding, nucleolar organizer regions (NORs) and location of GC-rich DNA sites on chromosomes have been useful in cyprinid taxonomy (Buth et al. 1991, Boroń 2001).

Some papers (Raicu et al. 1973, Sofradžija and Berberović 1975, Hafez et al. 1978, Vujošević et al. 1983, Vasil'ev 1985, Klinkhard et al. 1995) described this species as possessing, diploid number of $2 \mathrm{n}=50$ chromosomes, which is the most frequent among all other cyprinid lineages (Buth et al. 1991, Ráb and Collares-Pereira 1995).

\footnotetext{
* Correspondence: Dr Lech Kirtiklis, Katedra Zoologii, Wydział Biologii, Uniwersytet Warmińsko-Mazurski, ul. Oczapowskiego 5, 10-718 Olsztyn, Poland, phone (+48) 089 523-3319, fax (+48) 089 523-3261, e-mail: leo@uwm.edu.pl
} 


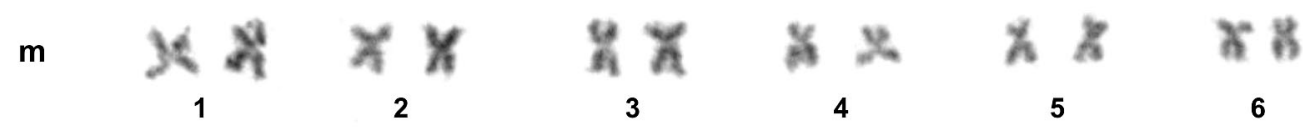

\begin{tabular}{|c|c|c|c|}
\hline$x \times$ & $x \times$ & $x \approx$ & $x x$ \\
\hline & 8 & 9 & \\
\hline
\end{tabular}

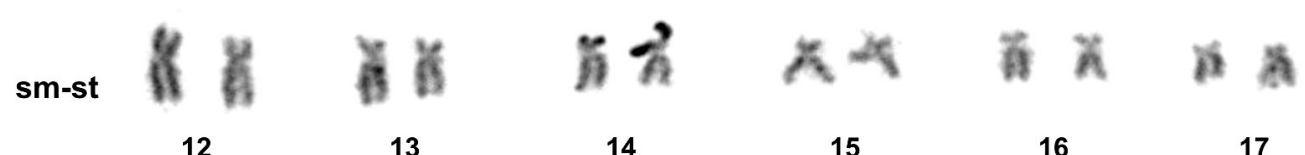

$\begin{array}{llllll}12 & 13 & 14 & 15 & 16 & 17\end{array}$

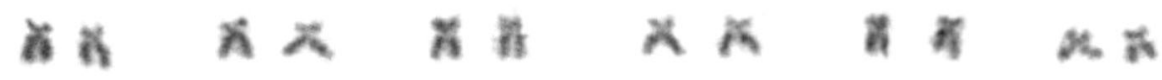

$\begin{array}{llllll}18 & 19 & 20 & 21 & 22 & 23\end{array}$

म $\%$

24

a $\mathrm{a}$ b

25

a
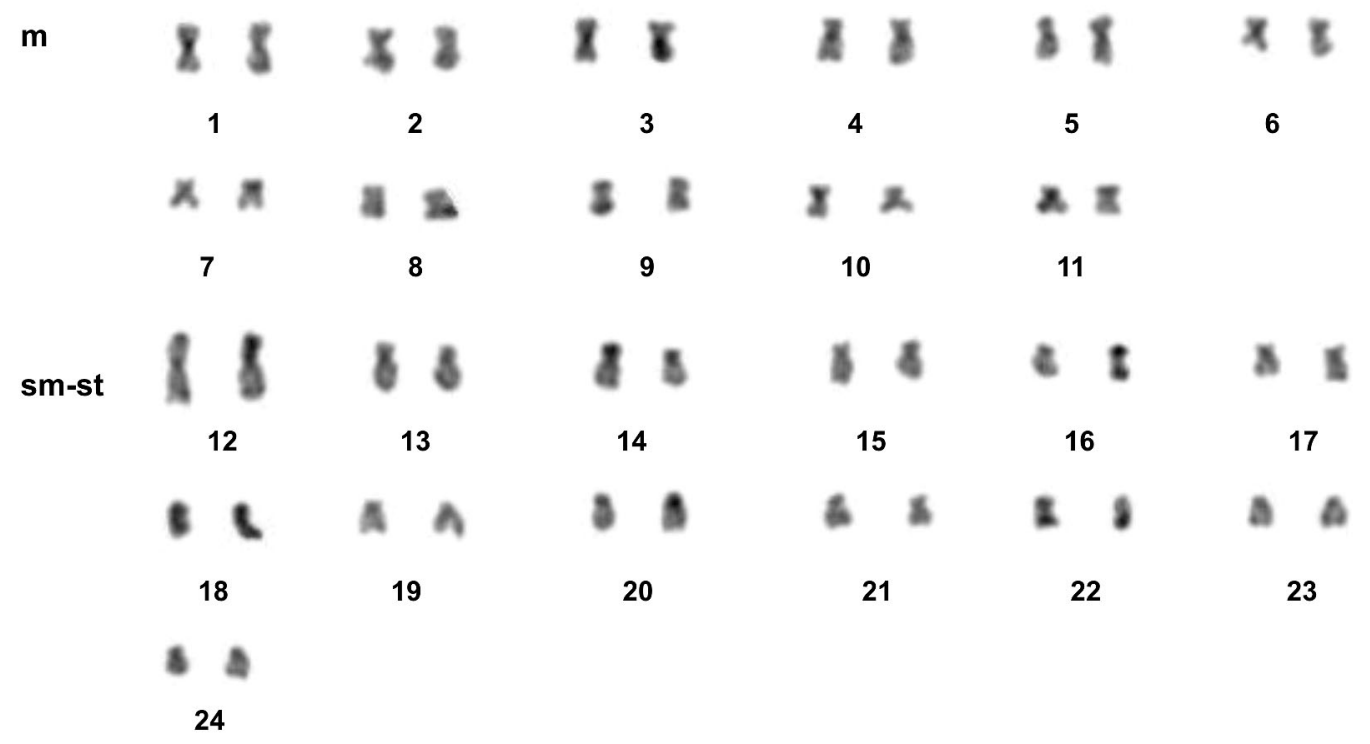

a

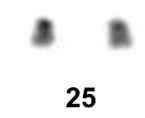

b

Fig. 1. Karyotype of the gudgeon, Gobio gobio: (a) after Giemsa plus Ag-NOR staining; (b) after C-banding 


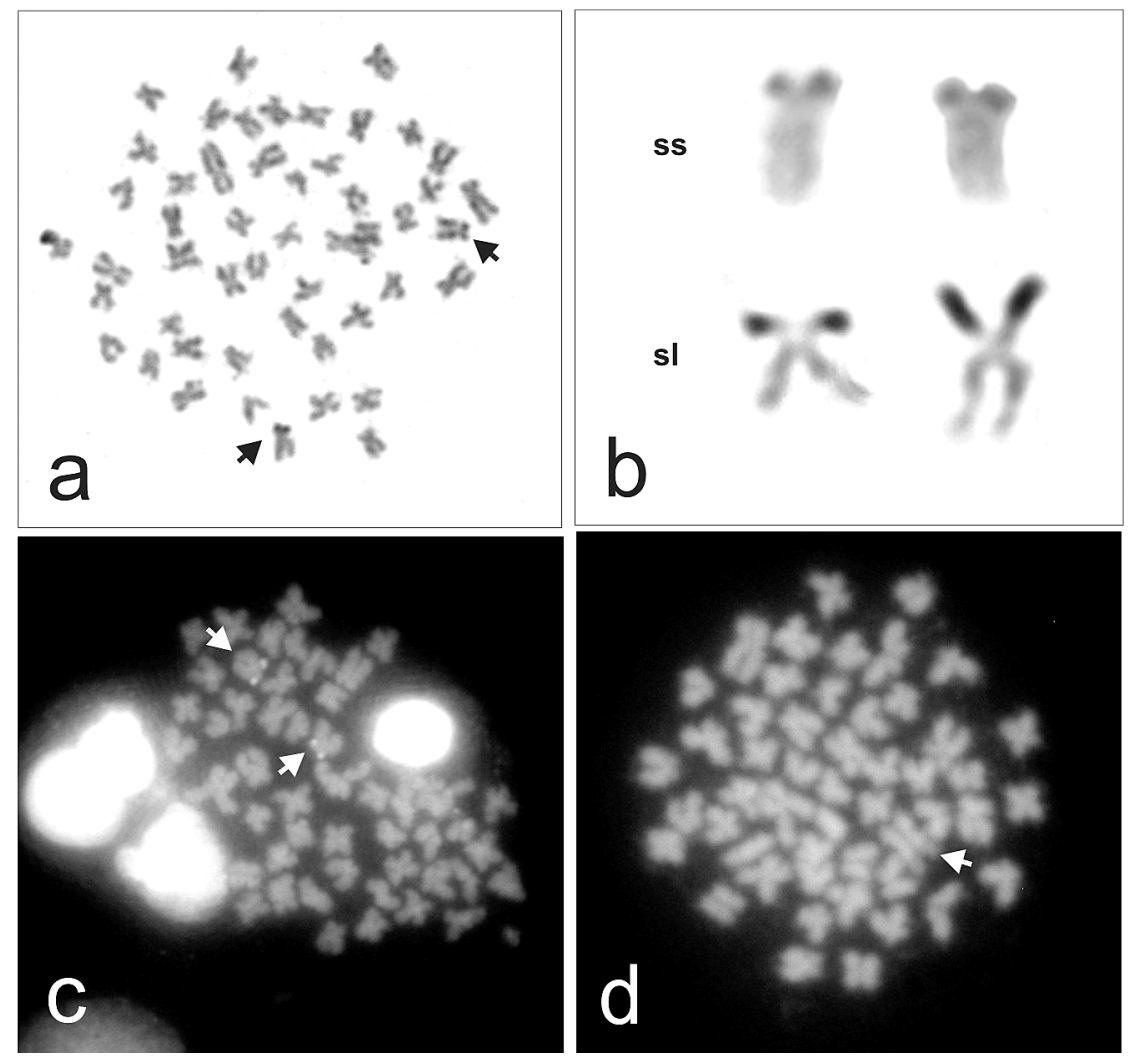

Fig. 2. Chromosomes of the gudgeon, Gobio gobio, after different staining: (a) Ag-NOR; (b) "ss" and "sl" cytotypes of NOR-bearing chromosomes; (c) chromomycine $\mathrm{A}_{3}$ (arrows indicate the NOR sites); (d) DAPI (arrow indicates sm-st chromosome).

In the presently reported study we provide, for the first time, a new data on the location of Ag-stained NORs, AT-rich DNA regions (stained with DAPI), and GC-rich DNA regions on the chromosomes of the gudgeon G. gobio from the upper part of the Odra River in Poland.

\section{MATERIALS AND METHODS}

Fifteen specimens (six males and nine females) of gudgeon from the Odra River, near Legnica, (Poland) were studied. Mitotic chromosome preparations were obtained from the head kidney by standard air-drying technique (Ráb and Roth 1988). Conventional 5\% Giemsa staining, C-banding (Haff and Schmid 1984), NOR sites by silver nitrate staining (Howell and Black 1980) and chromomycine $A_{3}$ staining (Sola et al. 1992) were applied. The distribution of A-T pairs on chromosomes was revealed by DAPI staining (Sola et al. 1992). The chromosomes were classified according to Levan et al. (1964).

\section{RESULTS}

All individuals of $G$. gobio were characterized by the same $2 n=50$ number of chromosomes. The karyotypes consisted of 11 pairs of metacentric chromosomes, 13 pairs of submeta-subtelocentric, and one pair of acrocentric chromosomes, NF = 98 (Fig. 1). Ag-NOR sites on one submeta-subtelocentric chromosome pair No. 14 were found (Fig. 2a). Two cytotypes with size polymorphism in the NOR-bearing pair were observed (Fig. 2b). Chromosome sites with G-C-rich regions were shown on one submeta-subtelocentric pair
(Fig. 2c). C-positive blocks of heterochromatin mainly in the centromeric regions in some chromosomes pairs were detected (Fig. 1b). DAPI staining revealed A-T pair rich regions on "q" arm of one submeta-subtelocentric chromosome (Fig. 2d).

\section{DISCUSSION}

The chromosome diploid number of G. gobio $2 \mathrm{n}=50$ and diploid arm number (NF) ranging from 88 to 98 have been reported by other authors (Raicu et al. 1973, Sofradžija and Berberović 1975, Hafez et al. 1978, Vujošević et al. 1983). The same number of chromosomes was obtained in the presently reported study, and this feature is stable for the species of the genus Gobio, except Gobio uranoscopus from Slovakia with $2 \mathrm{n}=52$ chromosomes (Ráb and Collares-Pereira 1995). Diploid arm number NF $=98$, determined in the present paper, and chromosome formulae of the gudgeon $2 \mathrm{n}=50 ;(11 \mathrm{~m}+13 \mathrm{sm}-\mathrm{st}+1 \mathrm{a})$ (Fig. 1) is similar with the results of the specimens from other populations previously described.

The majority of the European species, as well as most of other cyprinid fish species of North America, possessed single NOR-bearing chromosome pair (only about $30 \%$ species had multiple NOR sites) (Buth et al. 1991, Klinkhard et al. 1995). In cyprinids, NORs are located on all type of the chromosome (from metacentric to acrocentric) (Foresti et al. 1981, Galetti et al. 1985, Galetti jr. et al. 1984, Moreira-Filho et al. 1984, Takai and Ojima 1986), but in European species NORs are mainly located on sm/a chromosomes (Ráb and Collares-Pereira 1995). Classical rearrangements (inversion and translocation) are the most causes of interspecific NOR chro- 
mosome differences (Gold and Amemiya 1986, Amemiya and Gold 1988). Silver nitrate staining, which was done for the first time in this species, shown one sm-st NOR bearing chromosome pair (Fig. 2a). The size polymorphism of NORbearing chromosomes (pair No. 14) was observed in two individuals, and they have been described as two cytotypes "ss" and "sl" (Fig. 2b). The NORs enlargement that is an effect of amplification is common among different fish species including cyprinids. Size differences between homologous NORs have been found in other fish species (Sanchez et al. 1990, Jankun et al. 2003) and amphibian (Schmid 1982). Amplification or deletion of NOR sites could be an effect of the crossing-over disorders caused by wrong meiotic conjugation between repetitive nucleotide sequences of homologous chromosomes (Schmid and de Almeida 1988). These kinds of chromatin rearrangements lead to inactivation of NOR site (Foresti et al. 1981, Moreira-Filho et al. 1984, Takai and Ojima 1986).

Distribution of heterochromatin in cyprinids generally is limited to centromeric regions and NOR sites (for review see: Klinkhardt et al. 1995, Ráb and Collares-Pereira 1995), but also some species with different type of heterochromatin location were found (Boron 2001). C-positive blocks of heterochromatin in the centromeric regions of some investigated chromosomes in gudgeon are presented in this study (Fig. 1b).

In several cyprinid species there is non specific DAPI heterochromatin (Mayer et al. 1986, Schmid and Guttenbach 1988). In all investigated specimens, one small signal on a "q" arm of sm-st large chromosome after DAPI staining were found (Fig. 2d) that could be an effect of low accumulation of A-T pairs in gudgeon genome.

Using classical cytogenetic methods presented in this some species specific chromosome markers were found. However, they seem to be not sufficient for more detailed differentiation and identification of the gudgeon chromosomes. So, the next step using the molecular cytogenetic techniques (Fluorescence In Situ Hybridization-FISH) to enable identifying and description of some specific sequences on chromosomes are required.

\section{ACKNOWLEDGEMENTS}

We thank Dr S. Boron for kindly providing the fish for the examination. This study has been financially supported by the research grants No. 0208.805 and No. 0208.211 from the University of Warmia and Mazury in Olsztyn, Poland.

\section{REFERENCES}

Amemiya C.T., Gold J.R. 1988. Chromosomal NORs as taxonomic and systematic characters in North American cyprinid fishes. Genetica 76: 81-90.

Bănărescu P. 1992. A critical updated checklist of Gobioninae (Pisces, Cyprinidae). Travaux du Muséum d'Histoire naturelle „Grigore Antipa“, Bucarest 32: 303-330.

Bănărescu P. 1999. Genus Gobio. pp. 33-202. In: Bănărescu P. (ed.) The freshwater fishes of Europe. Vol.5 /I: Cyprinidae 2/I. Aula-Verlag, Wiebelsheim.

Boron A. 2001. Comparative chromosomal studies on two minnow fish, Phoxinus phoxinus (Linnaeus, 1758) and
Eupallasella perenurus (Pallas, 1814); an associated cytogenetic-taxonomic consideration. Genetica 111: 387-395.

Buth D.G., Dowling T.E., Gold J.R. 1991. Molecular and cytological investigations. pp. 83-125. In: Winfield I.J. and Nelson J.S. (eds.) Cyprinid fishes, systematics, biology and exploitation. Chapman and Hall, London.

Foresti F., Almeida Toledo L.F., Toledo S.A. 1981. Polymorphic nature of nucleolus organizer regions in fishes. Cytogenetics and Cell Genetics 31: 137-144.

Galetti P.M., DaSilva E.B., Cerminaro R.T. 1985. A multiple NOR system in the fish Serrasalmus spilopleura (Serrasalminae, Characidae). Brazilian Journal of Genetics (Revista Brasileira de Genetica) 8: 479-484.

Galetti jr. P.M., Foresti F., Bertollo L.A.C., Moreira-Filho O. 1984. Characterization of eight species of Anostomidae (Cypriniformes) fish on the basis of the nucleolar organizing regions. Caryologia 37: 401-406.

Gold J.R., Amemiya C.T. 1986. Cytogenetic studies in North American minnows (Cyprinidae). XII. Patterns of chromosomal NOR variation among fourteen species. Canadian Journal of Zoology 64: 1869-1877.

Haaf T., Schmid M. 1984. An early stage of ZW/ZZ sex chromosome differentiation in Poecilia sphenops var. melanistica (Poeciliidae, Cyprinodontiformes). Chromosoma 89: 37-41.

Hafez R., Labat R., Quiller R. 1978. Etude cytogenétique chez quelques espèces de cyprinides de la région Midi-Pyrénées. Bulletin de la Société d'Histoire Naturelle de Toulouse $\mathbf{1 1 4}$ (1-2): 122-159.

Hosoya K. 1986. Interrelationships of the Gobioninae (Cyprinidae). pp. 484-501. In: Uyeno T., Arai R., Taniuchi T., Matsuura K. (eds.) Indo-Pacific fish biology: Proceedings of The Second International Conference on Indo-Pacific Fishes. Ichthyological Society of Japan, Tokyo.

Howell W.M., Black D.A. 1980. Controlled silver-staining of nucleolus organizer regions with a protective colloidal developer: a 1-step method. Experientia 36: 1014-1015.

Howes G.J. 1991. Systematics and biogeography: an overview. pp. 1-33. In: Winfield I.J., Nelson J.S. (eds.) Cyprinid fishes, systematics, biology and exploitation. Chapman and Hall, London.

Jankun M., Ocalewicz K., Pardo B.G., Martinez P., Woznicki P., Sanchez L. 2003. Chromosomal characteristics of rDNA in European grayling Thymallus thymallus (Salmonidae). Genetica 119: 219-224.

Klinkhardt M., Tesche M., Greven H. 1995. Database of fish chromosomes. Westarp Wissenschaften Verlag, Magdeburg.

Levan A., Fredga K., Sandberg A.A. 1964. Nomenclature for centromeric position on chromosomes. Hereditas 52: 201-220.

Mayr B., Ráb P., Kalat M. 1986. NORs and counterstainenhanced fluorescence studies in Cyprinidae of different ploidy level. Genetica 69: 111-118.

Moreira-Filho O., Bertollo L.A.C., Galetti jr. P.M. 1984. Structure and variability of nucleolar organizer regions in Parodontidae fish. Canadian Journal of Genetics and Cytology 26: 564-568.

Naseka A.M. 1966. Comparative study on the vertebral column in the Gobioninae (Cyprinidae, Pisces) with special refer- 
ence to its systematics. Publicaciones Especiales. Instituto Español de Oceanografia 21: 149-167.

Ráb P., Collares-Pereira M.J. 1995. Chromosomes of European cyprinid fishes (Cyprinidae, Cypriniformes): a review. Folia Zoologica 44 (3): 193-214.

Ráb P., Roth P. 1988. Cold-blooded vertebrates. pp. 115-124. In: Balicek P., Forejt J., Rubes J. (eds.) Methods of chromosome analysis. Cytogenetic Section of the Czech Biological Society, Brno.

Raicu P., Taisescu E., Bănărescu P. 1973. A comparative study of the karyotype in the genus Gobio (Pisces, Cyprinidae). Cytologia 38: 731-736.

Sanchez L., Martinez P., Vinas A., Bouza C. 1990. Analysis of the structure and variability of nucleolar organizer regions of Salmo trutta by C-, Ag- and restriction endonuclease banding. Cytogenetics and Cell Genetics 54: 6-9.

Schmid M. 1982. Chromosome banding in Amphibia. VII. Analysis of the structure and variability of NORs in Anura. Chromosoma 87: 327-344.

Schmid M., de Almeida C.G. 1988. Chromosome banding in Amphibia. XII. Restriction endonuclease banding. Chromosoma 96: 283-290.

Schmid M., Guttenbach M. 1988. Evolutionary diversity of (R) fluorescent chromosome bands in vertebrates. Chromosoma 97 (2): 101-114.

Sofradžija A., Berberović L.J. 1975. Osnovni podaci o chromosomskoj garnituri vrste Gobio gobio (Linnaeus 1758),
Cyprinidae, Pisces. [Basic data about chromosome complement of the species Gobio gobio (Linnaeus 1758), Cyprinidae, Pisces.] Acta Biologica Jugoslavica Ichthyologia 7: 53-59. [In Serbo-Croatian.]

Sola L., Rossi A.R., Laselli V., Rasch E.M., Monaco P.J. 1992. Cytogenetics of bisexual/unisexual species of Poecilia. II. Analysis of heterochromatin and nucleolar organizer regions in Poecilia mexicana mexicana by C-banding and DAPI, quinacrine, chromomycin $\mathrm{A}_{3}$ and silver staining. Cytogenetics and Cell Genetics 60: 229-235.

Takai A., Ojima Y. 1986. Some features on nucleolus organizer regions in fish chromosomes. pp. 899-909. In: Uyeno T., Arai R., Taniuchi T., Matsuura K. (eds.) Indo-Pacific fish biology: Proceedings of The Second International Conference of IndoPacific Fishes. Ichthyological Society of Japan, Tokyo.

Vasil'ev V.P. [Vasiliev V.P.] 1985. Êvolûcionnâ kariologiâ ryb. [Evolutionary karyology of fishes.] Izdatel'stvo Nauka, Moskva. [In Russian.]

Vujošević M., Živković S., Rimsa D., Jurišić S., Cakić P. 1983. The chromosomes of 9 fish species from Dunav basin in Yugoslavia. Acta Biologica Jugoslavica - Ichthyologia 15 (2): $29-40$

Received: 27 September 2005 Accepted: 17 November 2005 